\title{
The Potential for Creative Socio-cultural Energy of Coastal Communities in the Maluku Islands
}

\author{
Idrus Hentihu $^{1^{*}}$, Sumardjo², Basita Ginting Sugihen ${ }^{2}$ and Djoko Susanto ${ }^{2}$ \\ ${ }^{1}$ Iqra Buru University, Namlea, Indonesia. \\ ${ }^{2}$ IPB University, Bogor, Indonesia.
}

\begin{abstract}
Authors' contributions
This work was carried out in collaboration among all authors. Author IH designed the manuscript, analyzed and wrote the results of field studies. Author Sumardjo helped to design the analysis and improve the results of field study, whereas authors BGS and DS helped to improve the field study analysis results. All authors read and approved the final manuscript.
\end{abstract}

Article Information

DOI: 10.9734/ARJASS/2020/v11i330173

Editor(s):

(1) Prof. K. N. Bhatt, Allahabad Central University, India.

Reviewers:

(1) Husein Mohamed Irbad, Annamalai University, India. (2) Ahmad Albattat, Management and Science University, Malaysia. (3) Chung-Jen Wang, National Pingtung University of Science and Technology, Taiwan. Complete Peer review History: http://www.sdiarticle4.com/review-history/56004

Case Study

Received 06 February 2020

Accepted 10 April 2020

Published 14 August 2020

\begin{abstract}
The coastal areas of the Maluku Islands are the most prominent poverty-polarizing areas, both physically and socially with relatively isolated geographical positions. The social energy of creative culture has the potential to become a social resilience scheme in realizing welfare based on common interests. This qualitative study was conducted in Buru Island, Maluku Islands and aims to explain the potential of socio-cultural energy as a scheme of community social resilience in survival on the coast of Buru Island, Maluku Islands. The results of this study show that there is a potential for energy creative social culture that serves as a community social resilience scheme, where through this potential although in limited circumstances and conditions, the community seems to be able to find a way out of a variety of problems, including the poverty problems they faced to stay alive. Meanwhile, on the potential of social energy, This then becomes a force and even a guideline for the community independently through creative and constructive efforts turned out to be able to empower themselves and its community to get out of trouble Including the problem of poverty, which is now a major problem for people living on the coast of Buru Island.
\end{abstract}


Keywords: Social energy of creative culture; coastal communities; poverty; Maluku Islands.

\section{INTRODUCTION}

The coastal areas of the Maluku Islands are the most prominent regions of poverty, both physically and socially with relatively isolated geographical positions. As a community, communities in rural life are not only isolated but also lagged compared to surrounding areas [1]. Unlike people living in urban areas that have complete public infrastructure and have excellent access, people living in rural areas still live with public facilities and infrastructure. According to the Central Statistics agency report, in 2018, the number of poor people in the Maluku recorded 320,850 inhabitants or 18.12 percent. The rural area is identified as a bag of poverty with a poor population of 274,190 people or 26.64 percent [2].

Socio-cultural energy has the potential to become a social resilience scheme in realizing the welfare based on the common interest of participatory built-in for survival. Social energy from creative culture as a social potential owned by society [3], seems to be gaining serious attention in the process of community empowerment to hack various socio-economic problems that are now happening on the coast of Maluku Islands. There are several important findings, related to the importance of creating social energy in development. The existence of social energy as one of the social potentials can be utilized for development. In his studies in East Nusa Tenggara province, shows that local leaders in rural areas are one of the most creative social energy cultures that have the potential to mobilize communities in an effort to improve the welfare of Together. In addition, the existence of local leaders in rural areas can be the legitimator of an effective idea in encouraging the development process at the local level [3].

Socio-cultural energy is the "energy in" that is owned by the community as a mechanism to address the problems faced independently $[3,4$, 5]. Socio-cultural energy is owned by the community, seen from its founding able to foster increased fate together in various social bonds (solidarity) and various cooperation relationships [4 Sayogyo 1994]. Theoretically, this sense points to the proposition, that in society there is a social energy culture which is an internal force pointing to the mechanism of dealing with the problem itself $[3,4,5]$. If the problem of poverty, society through the existence of social culture energy can be directed to overcome the problem of poverty, whether it is limited to overcome the consequences or overcome the cause. Energy social culture as social capital. Social capital requires the public to be empowered to meet the needs of prosperity [6].

In addition to natural resources, people also have social and cultural resources that serve as their buffer needs. This potential, when excavated and transmitted, will be a great energy for the alleviation of various social problems, including the problem of poverty. How to explore and empower the resources in this community that is the essence of community empowerment in the empowerment of the important community is how to make the community in the position of active development actors and not Passive recipients. The concept of Community empowerment movement in establishing the prioritisation of initiatives and community creation, with the basic strategy of giving power to society [7].

In terms of community development, capacity building in community development has the meaning to bring out the encouragement and energy of the community. Social energy is a kind of energy in society that can move the action together to independently improve the condition of its life or defend yourself from various threats and challenges. Social energy is necessary because of the effort to realize expectations and shared interests instead of individual actions but collective action. In the life of social energy societies manifested in the form of social responsibility, social solidarity, and mutual trust. Three things can be obtained through the process of social interaction [8].

The poor in particular, and society, in general, have a value system and a social institution that has been able to "buffer" to the onset of life difficulties. The social energy of the culture that grows and nurtured in the lives of village people should be able to acquire a place as a development potential that is actively involved in all phases of the building namely about itself. Social energy culture manifested in the social solidarity community in the village, as described in previous research, that the high social solidarity between siblings has been able to be a buffer for poorer relatives when Having trouble food $[9,10]$.

In the era of regional autonomy, the problem of resource limitations in this region has always been a constraint in performance development, 
but with the use of creative social energy as a social resource will greatly help the implementation of development in the area is based on the resilience and independence of the region. In his study in Pacitan Jawa Timur, explained that the social energy of the creative culture owned by the community, in addition to being a social capital (social capital) that serves to ensure the common welfare of citizens and local communities Community, also serves as a network of cooperation with outside parties, including with local governments [11].

Also, in another study, explained that in rural communities who belong to the farming group there is a creative social energy that is present with a culture of reciprocal assistance in addressing the problems arising and creating Strong solidarity between them. The group is generally based on the bonds of kinship and beyond the family system (kinship). Various forms of cooperation built with various parties is a manifestation of the potential energy creative social culture developed to meet the needs of the group. In many cases, the presence of local leadership, especially in the group, is a potential social energy creative culture that has been displaced as a mobilizer in providing motivation and information to members about sharing matters relating to Efforts to achieve the goals of the group [12].

Meanwhile, the study conducted in East Nusa Tenggara province shows some form of social energy in the community. First, the case of the house of arisan in the village Wonda. It has a habitable home to be a desire (mind) among the sub-tribes even though they are in poor condition. This dream is manifested by the idea (idea) of one of the sub-tribe members who have gained experience in another village to build a permanent home by arisan. To achieve the idea, members of kinship in the corresponding subtribe organized an arisan or partnership in taking turns (friendship) in building houses among the members of the sub-tribe. This idea and cooperation extend to other sub-tribes in the village concerned. Second, the organizer or ceremonial ceremony in West Sumba where the kabisu system is still functioning. The great economic-based feast of all members of Kabisu, the prestige of Kabisu is demonstrated by the excitement of traditional ceremonies to become the dream (ideas) of every kabisu. This ideal is manifested by the idea of the contribution of the massacre among the members of the relatives in kabisu with the principle of the brotherhood [4].
The importance of social energy in creative culture is one of the potentials in development. The existence (social energy) is important to be deployed and is used to improve the welfare of the people [Ollet A and Kayam (1999) Soetomo]. Also, the social energy of creative culture should be taken into account as a resource in the movement of accelerating the development [13, 14,15]. In the same sense, regarding the interests of development, the existence of a creative culture of social energy is the basis of the strength of the internal (power) society that must be developed to realize the purpose of development is welfare Society [16]. At this point, the social energy of creative culture which became the focus of the study in the research was then considered important, where the potential social energy of creative culture owned by the community as a social capital required the community to be fulfilling prosperity needs.

Regarding the research done, theoretically, the concept of creative social culture is viewed as "energy in" that is owned by the community as a mechanism to address the problems faced independently. The social energy of creative culture owned by the community, seen from its founding, can encourage increased fate together in various social bonds (solidarity) and various cooperation relationships. In a theoretical framework, the social energy potential of the creative culture in the countryside can be seen in four important aspects namely; (1) kinship unit, (2) social unit, (3) the original welfare and social security system, and (4) local leadership. These four aspects can be a viable development potential to count towards the development of the move. The potential development in question is the "power" of the society itself that is sourced from the solidarity that is evidenced through its ability independently in the effort to improve the fate of the community concerned.

In this context, this study demonstrates how to find and build internal energy owned by the community, by encouraging, motivating, and raising awareness of its potential and attempting to develop it. This departs from the concept of empowerment that is to ensure that every community has a variety of potential sources, one of which is the social energy of creative culture as a social capital that can be developed to improve community empowerment. Thus, the empowerment process will then be directed on how to strengthen the potential (social energy) of the community that has been through the process of alertness. 


\section{CASE STUDY}

The study of the social energy of creative culture in coastal communities in the Maluku Islands was held for 6 months in the period from January to August 2019 in Wamlana village, Finalisela District, Buru Regency, Maluku Islands. Through a qualitative research approach with case study methods, this study focuses on the potential of creative social energy Culture (hereinafter referred to as Social energy) as a social force that could potentially be able to impoverish social issues, including the poverty problem.

Referring to the opinions of Creswell [17], qualitative research is part of a set of interpretive material practices that make the world observable. In the meantime, the case study method used in this research was, which is to consider that this method allows researchers to investigate empirical phenomena in the context of their environment so that the relationship between the phenomenon and the untransparent environment will be revealed.

The data collected in this study consists of secondary data and primary data. Secondary data in the form of village demographic data as well as other documents relevant to research purposes. Meanwhile, primary data is sourced from direct observation to the field, unstructured interviews, and in-depth interviews. Direct observation to the field, intended to know and see directly the various contexts, symptoms and behaviours of the actors. The results of this observation in addition to collecting field facts are also used as a basic clarification and crosscheck of various information and phenomena revealed. Unstructured interviews are freelance interviews with informers, where researchers prepare first-of-all questions for information and deeper explanations of informers related to the topic of research. In-depth interview, it is intended to know the more profound and comprehensive qualitative aspects of key informant with competence with the studies studied. The snowball method is applied to select Informant.

Referring to research objectives, this study begins with the analysis of the potential social energy of creative culture found in coastal communities in the Maluku Islands. The potential of social socio-cultural energy is analyzed in three aspects of local institutional as follows. First, a unit of kinship: regarding the kinship ties that exist in each social environment in the face and overcoming of a problem or need. Secondly, the unit of locality: a form of cooperation in local communities outside of family and kinship systems, such as each other, arisan, and other forms of cooperation. Third, the social security system and traditional welfare: the form of cooperation in local communities, such as each other, Arisan, and other forms of cooperation that are to ensure the welfare and social resilience. Fourth, local leadership: The local leadership has the potential as social energy that serves to lead the community towards mutual welfare achievement. Local leadership in the countryside rests primarily on indigenous, religious, and formal leaders of village governments.

To collect the above primary data, researchers equip themselves with research instruments in the form of Interview guides (guide interviews), recording tools, digital cameras and log books. Furthermore, in order to obtain the credibility of the research data, the researchers took several steps, such as Guba and Lincoln suggested (2000) as follows: (1) repeated observations, i.e. observation by visiting the location back and forth, (2) triangulation, ie checking data from various sources in various ways and time. Thus there is the triangulation of the source, triangulation of the data collection techniques and triangulation time, and (3) the input of the informant, that all conclusions as a result of this research are then confirmed back to the resource to prevent misinterpretation.

Furthermore, data that has been collected is then analyzed following qualitative research rules that are through phase: 1) data reduction, which is sorting and summarizing the data obtained into the socio-cultural potential of creative social energy; 2) Presentation of data in the form of matrices; 3) Withdrawal of conclusions and interpretation of the field findings are attributed to other research results [17].

\section{RESULTS AND DISCUSSION}

Although despite being in limited circumstances and conditions, people living in the countryside of Buru Island especially in coastal communities and the mountains seem able to hack the way out of various life issues that are in the areas, including poverty problems. Referring to the thesis that was discovered [4], that "the fate of a society will not be better except for the effort of self-struggle" seems to have relevance to these findings. Related to this, the study succeeded in strengthening the potential of power for the 
people in the fight for the fate of the joint to remain alive. The potential in question is social energy culture.

The potential of socio-cultural energy as shown in Table 1 is then a force and even a guideline for the community to hack the various social issues that are wrapped around them based on independent struggles and Conducted in a participatory environment. The above shows that the community can empower itself and its community to improve the circumstances he faced. Without reprove the efforts of external parties (government, NGOs, private) in empowering the community, but apparently behind this effort seemed to the community through its independent and creative struggle also continually seeks to escape the problem Social media that wrapped around them. For researchers, it is not much said by some previous studies that the community can independently through creative and contractual efforts to empower themselves and its communities to escape the social problems that are in the Including the problem of poverty which is now a major issue for people living in the rural Buru Island.

As meant by socio-cultural energy is "internal power" of society that is sourced from social solidarity, through its ability independently able to strive to realize the common welfare. Social solidarity is reflected in the tradition of please help which in some cases appears to be a social resilience scheme for the community in establishing cooperation based on the spirit of fraternity ties. Please help is a prominent characteristic that stands out in rural Buru Island and to date continues to remain in the life of society as part of the human value manifestation of society to relieve its fellow burden. The term katong samua basudara (we are all brothers) is a reflection of the value of humanity that is a guide for each society in realizing the welfare together.

The three main components of socio-cultural energy are: idealism, ideas, and friendship [3-5]. The three components, well explained in every

Table 1. Potential of the socio-cultural creative energy of coastal communities in the Maluku Islands

\begin{tabular}{|c|c|c|c|c|}
\hline \multirow{2}{*}{$\begin{array}{l}\text { Elements } \\
\text { social } \\
\text { energy } \\
\text { creative } \\
\text { culture }\end{array}$} & \multicolumn{4}{|c|}{ Energy scope creative social culture } \\
\hline & Kinship unit & Unit locality & $\begin{array}{l}\text { Traditional welfare } \\
\text { and social security } \\
\text { system }\end{array}$ & $\begin{array}{l}\text { Local } \\
\text { leadership }\end{array}$ \\
\hline Ideal & $\begin{array}{l}\text { - Ideal home } \\
\text { ownership } \\
\text { - Education } \\
\text { access } \\
\text { - Health } \\
\text { Access } \\
\text { - Traditional } \\
\text { family } \\
\text { ceremony }\end{array}$ & $\begin{array}{l}\text { - Ceremony/customary } \\
\text { party of the country } \\
\text { - Ownership of House } \\
\text { of worship } \\
\text { - Livelihood access }\end{array}$ & $\begin{array}{l}\text { - Natural resource } \\
\text { access } \\
\text { - Local food access }\end{array}$ & $\begin{array}{l}\text { - Agricultural } \\
\text { land access } \\
\text { - Residential } \\
\text { land access }\end{array}$ \\
\hline Ideas & $\begin{array}{l}\text { - Construction } \\
\text { of houses } \\
\text { - Educational } \\
\text { savings } \\
\text { - Health } \\
\text { savings }\end{array}$ & $\begin{array}{l}\text { - } \text { Community } \\
\text { plantation } \\
\text { - Harbour boat } \\
\text { - Family housing }\end{array}$ & $\begin{array}{l}\text { - Sasi tradition } \\
\text { - Local food } \\
\text { institutional } \\
\text { (paparisa/ } \\
\text { papalele) }\end{array}$ & $\begin{array}{l}\text { - Land } \\
\text { sertification } \\
\text { - Division of } \\
\text { agriculture } \\
\text { land } \\
\text { - Distribution of } \\
\text { land } \\
\text { development } \\
\text { public means }\end{array}$ \\
\hline Freindship & $\begin{array}{ll}\text { - } & \text { Family } \\
\text { donation } \\
\text { - } & \text { Masaurat }\end{array}$ & $\begin{array}{l}\text { - Parusa tradition } \\
\text { - Public donation } \\
\text { - Kumpulan negeri }\end{array}$ & $\begin{array}{l}\text { - } \text { Masohi tradition } \\
\text { - Kay wai tradition } \\
\text { - } \text { Makanpatita } \\
\text { tradition }\end{array}$ & $\begin{array}{l}\text { - Legal and } \\
\text { customary } \\
\text { norms }\end{array}$ \\
\hline
\end{tabular}


effort made by the community in realizing the common welfare. This is the case, where participatory society is able to realize the objectives that will be achieved together, setting a planned idea to achieve the objectives by utilizing solidarity-kinship networks in support of achieving common goals Prosperity. Based on field observations, the potential of socio-cultural energy lies in the units of settlements, settlements, traditional social welfare and resilience systems, and local leadership.

In some cases, such as those found in the field, for example, if the problem is poverty, the sociocultural energy has been directed to overcome the problem of poverty, whether it is limited to overcoming consequences and overcoming the cause. In this context, the community independently as a subject or a major perpetrator in the effort to overcome the problem of poverty to realize idealized objectives. This effort is carried out through a participatory process through converging and dialogical communication as a bridge to generate convergence of interests and cooperation between them and the purpose of realizing. Through an independent and creative effort of participatory society with converging and dialogical communication approaches, problemsolving ideas are successfully formulated together and able to meet the ideal needs.

\subsection{Social Energy Potential in a Kinship Unit}

Kinship ties become a strong base of a mechanism of help between siblings, in order to realize the dream (ideals) together. Through the mechanism of help, a member of relatives who are economically "poor" turns out to meet the interests of high-budget socio-economic, such as home development, child education (to higher education level), and party organizing Marriage and customs. Please help is a reflection of togetherness that grows in the community environment in rural Buru Island. Please help as community spirit in establishing cooperation that can be utilized together, assuming that human beings are social creatures that can't live alone but the involvement of other human beings in various aspects of Life.

Please help among relatives members in an attempt to toss a child to a higher level is an example found in the countryside of Buru Island. Having a child with a high degree of education, like a scholar is a dream (idealism) among members of a relative. Through the idea of "family saving" idea initiated by one member of relatives, can fulfil the interest of child education (for higher education level). Related to this, the following as stated by the informant (NU 45 years) as the result of interviews conducted in the field.

“...These family savings I propose to the brother in the internal family. This idea departed from my concern for the economic condition of the family that is generally less capable so that many children who cannot access education to the college level..."

"...As a result of this condition many also decided to marry at a very young age. It seems to me that they still have hope to get goal goals for success. I think our children are the future of our family, they are the ones who later keep and continue generation in our family, so we must make solutions together and saving families is a solution that we can carry out together..."

The case of "family savings" in Wamlana village is an example that proves the strength of cooperation between members of relatives. The idea of this "family saving" has begun since 2013 and until now it proved to have been able to meet the needs of members of relatives to school their children into higher education levels. At least in the last five years, 7 child members were successfully deployed to a higher level of education. Even today, in addition to being made to meet the needs of education, it has also petrified other needs, such as wedding costs and health costs.

The practice of helping people in society form a mentality of the nation becomes more characteristic and gives birth to many sublime values that are beneficial to life. Similarly, in the community of Wamlana Village, please help among relatives reflect the principle of togetherness so as to form a sense of brotherhood that is much closer. Togetherness among relatives in Wamlana village that is interwoven in please help and give birth to the union between relatives. With unity, it appears that members of relatives become stronger and able to face various problems that arise.

\subsection{The Potential of Social Energy in Localities}

The locality refers to the context of social energy that exceeded the boundaries of kinship units. In rural Buru Island live various forms of 
cooperation outside kinship units such as arisan, please help, and various other non-governmental activities. The group of social energy is well depicted in the case in rural Buru Island. In the village of Wamlana, it has long been known as an arisan group called the country groups. The various groups of the arisan, such as money arisan, the food of the groceries, to cement and zinc arisan (roof house). In the case of food is one initiative that is initiated jointly by the mother group of Ta'lim to fulfill the needs of food before the month of ramadhan and idulfitri.

Like society in general, efforts to meet the needs of entering the month of Ramdhan directly and IdulFitri is the dream of every society. Nevertheless, the phenomenon of the surge in the price of staple needs that always happen in Ramdhan directly appears to be a problem for the community, especially mothers who often complain if there is a rise in food prices. In this issue, through the chairman of the Mother Group Ta'lim Council then the idea of the Arisan food is offered to other members of the group. There is a growing need for food, such as rice, meat, and others to be the reason for this food. The effort to fulfill the needs of this food such as the informant in the field (RF 46 years).

"...The food is already growing in Wamlana village since long ago. At this point, the idea is to direct the establishment of an arisan group to meet the needs of the household. But due to the increasing economic conditions and needs, we finally developed for some other activities, such as the one that is currently done is the food arisan..."

"...The idea is the result of an agreement with us through the joint dialogue of household needs that always require us to have to get it. Currently, through this idea, we have been able to answer one of the needs that always be our concern together that is the need for Eid Mubarak. The purpose of this food is derived from the problem of the fulfilment of basic food that is always difficult to get to enter the feast of Eid Mubarak..."

The basic food is a form of cooperation as a mechanism to mobilize the power of social collectivity in order to find solutions to the problem of increasing the needs of basic food. Another function is integrating the community into one social unity. Through the activities of the public food and community needs to feel bound, devoted to the group so that solidarity is made public. In terms of economics, the basic food is symbiotic economic cooperation which is mutually beneficial, participants should be helped with the existence of this activity as a means of saving.

Another form of arisan in Wamlana village is the arisan of zinc (roof of the house). Since the beginning of this notion is done, until the research is done seems to have provided a solution for society related efforts to transform the construction of houses from the house of sago roofs to be semi-permanent house zincroofed. The case of zinc arisan in Wamlana village is an example that shows how, with togetherness, the villagers managed to overcome the ownership of the habitable house.

In the local unit, the social energy community is reflected in cooperation please help. In the locality unit help each other as a marker of community social power. In addition, please help is the minimum level of social security schemes for the most vulnerable communities as well as the strength to build social cohesion [18].

Like the coastal Buru Island, please help be known as masohi. Masohi is a kind of tradition please help that develops in the middle of people's lives in rural island hunting. In essence, Masohi was part of the human value manifestation of society to relieve the burden of others. It is as stated by TU (65 years), which is one of the community leaders and also as the chairman of adat, as follows.

"...Masohi is a form of selfless cooperation that lives and develops throughout the life of the people of Ambon. In other words, Masohi is the embodiment of love and voluntary taste..."

Masohi is a value that has since been inherent and is part of the culture and civilization of Maluku. Masohi contains historical and cultural significance when the Maluku community especially Ambon do various activities in the village. Masohi is a prominent characteristic that stands out in the village of Buru Island that develops amidst the lives of people is essentially part of the human value manifestation of society to relieve the burden of others.

\subsection{Traditional Welfare and Social Security System}

In the coastal community Buru Island is still alive various traditional welfare systems and social resilience which is a traditional notion with prosperity. The notion of traditional welfare and 
social resilience, in some cases, seems to have been instituted through a form of customary tradition known as the term sasi. Sasi is a mechanism that the community uses to manage and utilize the potential of natural resources found on land, rivers, as well as beaches or seas on generations to fulfill food needs and improve the food needs of the community.

Conceptually, the traditional social welfare system, called community-based social security, is a social institution built on a common concern to address socioeconomic issues faced by the public. From a community perspective, social security can also be understood as public actions, including those undertaken by communities to protect the poor and weak from adverse changes in living standards, so that they have an acceptable standard of living.

In addition, traditional social security is interpreted as a part of the effort to maintain the survival of the needs of each other mechanism that is a social base in the implementation of traditional social security [19]. Related to this, following the narrative of some informant interviewed in the field.

“...Implementation of sasi as a rule or norm applies to regulate the time of utilization of natural results. This rule is based on local knowledge inherited from our ancestors associated with the cycle of marine resource development, such as fish and some other potential sea resources (KD 55 years)..."

"...For society in general, the existence of the sasi is a necessity and the realization that the rules are to maintain the availability of well-preserved marine resources, so that it will give a profit not only to the needs of the current society but also for the life of the next generation (RA 66 years)..."

Referring to the informant explanation above, it can be explained that sasi can be said as a traditional social security system built based on constructive ideas sought by the community through customary devices to fulfill the general expectations in the process taken by developing social bonds (solidarity) and cooperation. Social bonds and cooperation are fundamental to the social power of moving and developing the sasi to advance their lives.

In some cases in the rural areas of Buru, traditional communities through indigenous peoples successfully maintain and develop the potential of natural resources for the sustainability of life. Most of the island people hunt, especially in rural areas still have indigenous institutions in the management of natural resources that until now still remain and continue to be inherited and hereditary. Sasi is one of the local wisdom of society in the rural Buru Island which is passed down from generation to generation.

\subsection{Local Leadership Potential}

Leadership is the ability to move and direct people in the framework of cooperation to achieve the same goal $[20,21]$. In the case of rural Island Buru, there are two local leadership forces identified as social cultural energy, namely indigenous leadership and religious leadership. Both of these local leadership functionally, as successfully revealed in this study are known to be able to move people to realize the general well-being. Related to these findings, the theory strengthens the various forms of social cultural energy in rural areas expressed by Sumardjo, that local leaders living in the countryside are potential socio-cultural energy that can move people in business with improved welfare [3].

In the case in the village of Wamlana, these two local leaders have served as protectors, controllers, and guarantors of people's welfare through various social and cultural mechanisms that become the second strength based on leadership. In general, the power base of both local leaders is customary law. The most prominent local leadership is the customary leader.

As explained above, this customary leader has a power base which is customary law. Related to his role in realizing the general welfare, his active appearance is sasi. By referring to what is above, sasi is one of the customary laws held by indigenous leaders in organizing human life with nature as the basis for livelihoods. Related to this, the informant is found in the field.

“...Explicitly, sasi is generally understood as the "prohibition" relating to the utilization of natural resources, whether the sea, but the sasi is also part of the effort to sustain the survival of society in fulfilling the necessities of life. Citing the view of the community namely "man and nature is the unity of god in this world, so by aligning the life between human and natural welfare will be achieved..."

The existence of a relatively active sasi is not detached from the customary leader role. One 
example of sasi that seems still active until now is forest damar. In the village of Wamlana in addition to plantations, forest damar is one of the potentials of the village by some communities that serve as a livelihood to meet the needs of life.

The idea of a resin is derived from a conflict of forest issues between the contested forest area which has many potential resin. According to some informants interviewed, "...the conflict had taken the victim and ironically one of the clans in the village of Wamlana chose to leave the village because of the Battle of the forest area resin...".

Losing from the war and leaving shelter and looking for a new dwelling has become a habit, especially in the community in the rural Buru Island located in the mountains. This is why in some hilly villages many have small hamlets, one of which is associated with the conflict.

Departing from the above problems, through customary legal devices Indigenous leaders then took the initiative to create a sasidamar. Through customary legal devices this is intended to regulate and protect the public, so as not to conflict in the forest area of damar fighting. This gets a positive response from the community, because for the community if the forest damar is left free without well-arranged, the conflict still occurs. The positive response from society to this notion is also not detached from the lengthy process. Regardless of the process taken through the dialogue between the community and indigenous leaders and also prioritizes the family principle, finally, this idea is accepted as a common idea.

The role of adat leadership above differs considerably from the formal leader/village head. Since the change of village head directly selected by the community in the year 2017, began to emerge various issues in society. In the village of Wamlana, the role of village chief seems less prominent than that of the customary leaders regarding their efforts in encouraging communities to realize shared prosperity. In some cases, there is often an interest in inequality. The synergy between the interests of the community by village government policy is often not the case, so some development programs issued by village governments also often get negative responses from the community.

The development Program of wooden bridges that connect between community settlements is one example of how weak the role of village head in encouraging people to participate actively in village development. Interest inequality is one of the factors that sparked the participation of low society to participate in the development activities in the village. Citing the narrative of several informants interviewed, said the following:

"...Timber bridge construction is not a
necessity that the community needs to
answer the main problem in the village. For
people who are more important to answer
the needs of the community is the
development of clean water that is now
widely remembered by the community..."

The above shows that the role of the head of the village as it is contained in the task and function of the village head as motivators, facilitators, and mobilizers seem not to be maximally successful in doing. The village head seemed weak in motivating and facilitating the community in formulating participatory development activities and moving people to participate in development activities. Consequently, the activities undertaken by the village government are not welcomed warmly by the community.

Community participation in development is not an exertion of voluntary labour, but it is more important to be involved in public awareness in order to capitalize on opportunities to improve quality of life, family, and society. With that, it is understandable that when communities want to act towards improving self-lives and families it can only be said that the Community has participated in its development. In this context, participation must be resolved in order to benefit the participation and not only based on the willingness of sacrifice [6].

Weak leadership from village leaders has become a serious role. This relates to the reduction of public confidence in the policies of the village development, whose value is not aspirational. The village leadership pattern, for some of the communities he interviews, says that the village chief has not performed the maximum task and responsibility as the leader chosen by the community directly. One of the important notes cited in this issue is the unparticipatory pattern of leadership of village leaders. This is what makes the community seem to not overdo not even follow what the village government leads to various development agendas implemented in the village. 
On this issue, one of the problems of village head failure in moving people to be actively involved in village development is the pattern of leadership $[22,23]$. The head of the village has no imagination and strong initiative to mobilize and consolidate society in development. Village head or just busy with government administration activities and often forget the interests of the community.

Leadership segregation in the village of Wamlana seems obvious, where between informal leaders (customs and religion) and formal leaders (village heads) seem unsynergistic. This is evident from the inequality of interest that is in the wake through cooperation with the community. Adatleadership appears to be a more active role in moving people to engage in development activities, so the formal leader does not happen. Common interests or objectives become important records related to local leadership in the countryside.

As described above, local leadership at this formal leader/village chief at both locations of research seems to be a serious concern. The problem above shows that the social connections between governments and the public do not endure well. Social relations in the form of communication between citizens and governments must provide a way to reach an agreement to create prosperity in the community.

The interests of people who are often overlooked and not well converted have resulted in conflicts and social gaps always occur. Therefore, it takes responsivity or responsiveness from the village government to the aspirations and needs of the community. Responsivity means articulating the aspirations and needs of the community, which then process them into priorities of necessity and formulate them into village policies.

Referring to the explanation above, one important note is related to the development of a synergistic partnership between the village government and indigenous people in developing the ability of citizens to articulate their true needs through dialogue Participative and dialectical. Local leadership has the potential as social energy that serves to lead the community towards mutual welfare achievement. There is a tendency in the community in both research locations that the informal leadership that the community leaders have is not less effective with formal leadership. It is based on the village community's perception that informal leaders have superiority that must always be respected and obeyed. Thus, empowering the informal leaders in the countryside to be very important for the efforts of community empowerment, especially in rural areas.

\section{CONCLUSION}

Social energy is a creative social culture as a potential for the internal power of the community in addressing the problem independently. these internal strengths are sourced from three elements of creative social energy, namely, (1) ideas, hopes or ideals (ideals) and friendship. these three elements are functionally revealed in the community's self-reliant and independent efforts to fulfil the common hopes and ideals that in the process are pursued by developing family traits. as an internal force in survival, the social energy owned by the community is found in several aspects, namely the locality, the locality, the traditional welfare and social security system and local leadership.

In the area of kinship and locality, the case of house arisan is one example of the energy potential of creative culture that develops in coastal communities in Buru Island. Having a habitable home is a hope (ideals) among the members of relatives even though they are in poor condition. This hope is realized by the idea of one member of relatives to build a permanent house by arisan. Meanwhile, local leadership is one of the potential socio-cultural energy found in the coastal community on Buru Island. There are three local leadership strengths identified as social-cultural energy in moving communities to achieve the common welfare of Indigenous leadership, religious leadership, and formal village leadership.

The traditional welfare and social security system owned by the coastal community in Buru Island is the potential for creative social energy that materializes as a traditional notion of shared prosperity. One such idea is known as the term sasi. Sasi is interpreted as a mechanism used by the public to manage and exploit the potential of natural resources to meet the needs of the community.

The potential of creative social energy in society is well illustrated in this study of the community's ability to be able to cope with their own problems together. These skills are the way and the mechanisms of society to tackle the problem itself are facing. In other words, society can 
sustain its survival, even in insufficient conditions. The social energy potential of creative culture becomes a force and even a guideline for people to solve various social problems that happen to them based on participatory self-effort.

Through the social energy potential of the community's creative culture, it shows that people are able to empower themselves and their communities to improve their facing situation. Related to this, there have been many previous studies said that the community is able to independently through creative and contractual efforts to empower itself and its community to escape the social problems that are in the program, including the problem of poverty which is now a major issue for people living in the Maluku islands. Related to these findings, in an effort to empower people to look at the presence of social energy, the creative culture that is owned by the community needs to be strengthened by encouraging, motivating, and raising awareness of its potential and striving to develop it.

It became relevant to relate the strategy of poverty alleviation in the Maluku islands with the potential of social energy of creative culture owned by the community. In the context of development objectives, especially in alleviating poverty through community empowerment, the existence of social energy culture that is owned by the community can be developed so that the community can be empowered to meet the needs. Thus, the empowerment of the community taken through the Empowerment program can benefit the community, morally supported by the community and implemented by the community, and fulfill the needs and interests of the community.

In the context of development interest, apparently, the existence of social energy culture owned by the community needs to be deployed and utilized for development purposes, in addition, it should be taken into account as a development resource in determining Smooth development process in rural areas. The existence of social-cultural energy can't be dissociable from development as a base of social strength to be developed. At this point, the potential of socio-cultural energy owned by society needs to be calculated to be developed as a social capital required for the community to be empowered to meet the needs of prosperity.

\section{COMPETING INTERESTS}

Authors have declared that no competing interests exist.

\section{REFERENCES}

1. Pattinama MJ. Poverty alleviation with local wisdom (Case studies on BuruMaluku and Surade-West Java). Journal of Social Humanities. 2009;13(1):1-12.

2. BPS. Profile of poverty in Maluku. Ambon: Maluku Central Statistics Agency; 2018.

3. Sumardjo. Poverty and development in the province of East Nusa Tenggara. Jakarta: Obor Indonesia Foundation; 1994.

4. Sayogyo. Poverty and development in the province of East Nusa Tenggara. Jakarta; Indonesian Torch Foundation; 1994.

5. Uphoff N. Local institutional development: An analytical sourcebook with cases. West Hartford; Kumarian Press; 1986.

6. Sumardjo. Counseling towards the development of human capital and social capital in realizing people's welfare. Bogor; IPB Professor Scientific Oration; 2010.

7. Wisdom H. Community empowerment strategies. Bandung; Main Humanities; 2006.

8. Uphoff N. Local institutions and participation for sustainable development. London; Gatekeeper Series; 1992.

9. Soetarto E. Poverty and development in the province of East Nusa Tenggara. Jakarta; Indonesian Torch Foundation; 1994.

10. Sukesi K, Wisaptiningsih $U$, Nurhadi I. Madura women's spirit and social energy in the context of social change. Poor; Brawijaya University Malang Research Institute; 2013.

11. Masrukhi, Utari IS. Social energy in rural areas in empowering village development in Pacitan Regency, East Java. Journal of the Social Sciences Forum. 2017;43(1): 1-13.

12. Alim S, Winaryanto S, Mauludin. Potential of socio-cultural creative energy in the development of animal husbandry institutions in West Java. Bandung: DRPMI Padjajaran University Bandung; 2011.

13. Corten DC. People-centered development: Towards a framework. Jakarta; Indonesian Torch Foundation; 1988.

14. Erwin. The Mentawai community empowerment model through 
strengthening local institutions. Sosio Konsepsia Journal. 2015;4(2):1-14.

15. Norman U. Drawing on social energy in project implementation; a learning process experience in Sri Lanka. Boston; Paper prepared for presentation at the annual meeting of the American Society for Public Administration. Boston; 1987.

16. Sulistiani I, Sumardjo, Sugihen BS, Purnaningsih $\mathrm{N}$. The role of development communication in the development of socio-cultural energy for community empowerment in Papua. Journal of Communication and Development Research. 2017;18(1):43-56.

17. Creswell JW. Research design: Qualitative, quantitative and mixed methods approaches. London; Sage; 2014.

18. Saharudin. Empowerment of the poor based on local wisdom. Sodality Journal. 2009;3(1):17-44.
19. Ife J, Tesoriero F. Alternative community development in the era of globalization. Yogyakarta; Student Library; 2008.

20. Beer A. Local leadership roles in rural. Journal of Rural Studies. 2014;34:254262.

21. Davies A. Understanding local leadership in building the capacity of rural communities in Australia. Geograpichal Research. 2009;47(4):380-390.

22. Arini NW. Local leadership and sociopolitical life of women in two Balinese villages in the regency of Buleleng. Journal of Social Sciences and Humanities. 2014; 3(2):410-421.

23. Amrulloh AMK, Pramusinto $\mathrm{H}$. The influence of village head leadership, office facilities, and compensation on the performance of Sukorejo sub-districts. Economic Education Analysis Journal. 2017;6(3):912-922.

(c) 2020 Hentihu et al.; This is an Open Access article distributed under the terms of the Creative Commons Attribution License (http://creativecommons.org/licenses/by/4.0), which permits unrestricted use, distribution, and reproduction in any medium, provided the original work is properly cited.

Peer-review history:

The peer review history for this paper can be accessed here: http://www.sdiarticle4.com/review-history/56004 